\title{
Preservice Teacher Self-Efficacy for Enhancing Students' Long-Term Interest in Science
}

\author{
Davis Jean-Baptiste \\ School of Education, University of Newcastle \\ New South Wales, Australia, 2308 \\ E-mail: dlkjnbaptiste@gmail.com \\ David Palmer (Corresponding author) \\ School of Education, University of Newcastle \\ New South Wales, Australia, 2308 \\ E-mail: David.Palmer@newcastle.edu.au \\ Jennifer Archer \\ School of Education, University of Newcastle \\ New South Wales, Australia, 2308 \\ E-mail: Jennifer.Archer@newcastle.edu.au
}

Received: April 16, 2019

Accepted: May 20, 2019

Published: May 30, 2019

doi:10.5296/gjes.v5i1.14672

URL: https://doi.org/10.5296/gjes.v5i1.14672

\begin{abstract}
There is currently a great concern among educationalists regarding the widespread decline in student interest in school science. As a result of this decline, our future teachers will be faced with the challenge of enhancing their students' long-term interest in science. Yet it is not known whether they will have the dispositions necessary to achieve this. Teacher self-efficacy is known to be a relatively accurate predictor of teacher behaviour. The purpose of this study was to investigate preservice teachers' self-efficacy for enhancing students' long-term interest in science. The participants were 121 preservice primary teachers and 31 preservice secondary science teachers. Quantitative data were gathered using a survey, and qualitative data were gathered by interviews with 13 participants. It was found that both
\end{abstract}




\section{Macrothink}

Global Journal of Educational Studies

ISSN 2377-3936

primary and secondary preservice teachers had moderately positive self-efficacy. This was a welcome finding, because it suggests that if these levels of self-efficacy are maintained, then once they become practicing teachers they will have the necessary disposition to make vigorous efforts to enhance their future students' interest in science.

Keywords: Self-efficacy, Interest in science, Individual interest 


\section{Introduction}

Nearly all people have particular topics or activities in which they have an ongoing interest. These well-established and sustained interests have been referred to as individual interests. Renninger, Ewen, and Lasher (2002) defined individual interest as "the relatively enduring predisposition of a person to re-engage particular classes of objects, events, or ideas" (p. 467). This type of interest is educationally important: Ainley, Hidi, and Berndorff (2002) stated that the positive affect and persistence associated with individual interest "tends to result in increased learning. For example, the reader with an individual interest in ecology and conservation seeks opportunities to engage in associated activities and while so engaged experiences enjoyment and expands his or her knowledge" (p. 545). Thus, students who have a sustained interest in science have been found to experience greater conceptual change, greater science literacy, and greater achievement than those who do not have such interest (Jack, Lin, \& Yore, 2014; Linnenbrink-Garcia, Pugh, Koskey, \& Stewart, 2012; Randler \& Bogner, 2007).

Unfortunately however, there is a widespread decline in interest in science among school students. Rennie, Goodrum, and Hackling (2001) reported that many students find high school science to be "neither relevant nor engaging and does not connect with their interests and experiences” (p. 455). More recently, Kennedy, Lyons, and Quinn (2014) reported a continuing decline in science enrolments in Australian high schools, and Tytler (2007) stated that $61 \%$ of year 12 students who did not chose science stated that their reason was because they did not like it or they found science to be boring. This problem is of international concern, as Danaia, Fitzgerald, and McKinnon (2013) reported,

Over the last two decades, in a number of developed countries, there has been a growing concern about both the waning interest many high school students display towards science at school and the declining number of students pursuing science in the post-compulsory years of secondary education (p.1502).

Recent studies have noted declining interest in science among students in Canada (Potvin \& Hasni, 2014), Singapore (Oon \& Subramaniam, 2011), Germany (Tröbst, Kleickmann, Lang-Schubert, Rothkopf, \& Möller, 2016), and the UK (White \& Harrison, 2012).

Australian science curriculum documents have recognized the educational importance of enhancing student interest in science. In the NSW primary syllabus (Board of Studies, 2013) one of the Aims is, "to develop their understanding of, interest in [emphasis added], and enthusiasm for science" (p.14). Similarly, the NSW secondary science syllabus (Board of Studies, 2013) states that teachers should seek to develop students' "interest in and enthusiasm for science" (p. 79). This is also reflected in the aims of the Australian Curriculum (Australian Curriculum Assessment and Reporting Authority, 2015) in which it is stated that teachers should,

ensure that students develop an interest in science [emphasis added] as a means of expanding their curiosity and willingness to explore, ask questions about and speculate on the changing world in which they live (p.4) 
These syllabus statements imply that our future teachers will be faced with the challenge of creating a positive interest in science among their students. One problem however, is that it is not known whether our future teachers will have the dispositional attributes to achieve this aim. One of the most important factors that influence teacher behavior is their self-efficacy (Bandura, 1997). Previous research has found that when teachers feel efficacious about a task they will be more likely to make vigorous efforts and will eventually succeed in that task. Self-efficacy is therefore a good predictor of teacher behavior. However, it is not known whether preservice teachers feel efficacious about their ability to develop positive interest in science among their future students. This is the purpose of the present study.

\section{Theoretical Framework: Teacher Self-Efficacy}

Self-efficacy was defined by Bandura (1981) as "judgements about how well one can organize and execute courses of action required to deal with prospective situations that contain many ambiguous, unpredictable and often stressful elements" (p. 200). Thus, self-efficacy represents a belief in one's ability to perform a challenging task. Self-efficacy is important because people who have a high self-efficacy for a particular task will be more willing to attempt that task and will tend to persist with it when difficulties are encountered. Whereas individuals with low self-efficacy for that task will be more likely to avoid the task or give up when difficulties occur. Bandura (1997) stated that "different people with similar skills or the same person under different circumstances may perform poorly, adequately, or extraordinarily depending on fluctuations in their beliefs of personal efficacy" (p. 37). An important characteristic of self-efficacy is that it is specific to a particular task, and in this way it differs from constructs such as self-concept, self-worth, and self-esteem, which have more global connotations (Tschannen-Moran, Woolfolk Hoy, \& Hoy, 1998). Finally, Bandura (1997) proposed that the main sources of efficacy information are enactive mastery experiences (successful experience in performing the task), vicarious experiences (observing another person successfully performing the task), verbal persuasion (feedback from significant others), and physiological/affective states (levels of stress and fear).

Teacher self-efficacy is a construct that has been widely used to explain teachers' approaches to teaching. It has been defined as the "extent to which a teacher believed he or she has the capacity to affect student performance" (Tschannen-Moran et al., 1998, p. 202). Bandura (1997) argued that instructors with high teacher efficacy,

operate on the belief that difficult students are teachable through extra effort and appropriate techniques and that they can enlist family supports and overcome negating community influences through effective teaching. In contrast, teachers who have a low sense of instructional efficacy believe there is little they can do if students are unmotivated (p. 240).

According to Bandura (1997) teachers with a high sense of instructional efficacy do a better job of preparing lesson plans, managing classroom discussions and other instructional activities, tend to use persuasion rather than authoritarian control, and will support the development of their students' intrinsic interest. This in turn has positive effects on student learning and achievement. On the other hand, teachers with low instructional efficacy have a 
weaker commitment to teaching and spend less time on subject matter that may be challenging for students. For these reasons Tschannen-Moran and Woolfolk Hoy (2007) stated that self-efficacy is "a self-fulfilling prophesy" (p. 945). However, a teacher's instructional efficacy can vary from subject to subject, so a teacher who is highly efficacious in language may be less efficacious in science, or vise versa (Bandura, 1997).

\subsection{Science Teaching Self-Efficacy}

Many primary teachers have low self-efficacy for teaching science, and this has been a concern to educationalists for many years. Skamp (1991) for example, found that both preservice and inservice primary teachers had low confidence for teaching science (note that the term confidence has been used in some previous studies in place of self-efficacy). More recent studies have tended to confirm this pattern (Mansfield \& Woods-McConney, 2012; Palmer, Dixon, \& Archer, 2015; Sandholtz \& Ringstaff, 2011). Low self-efficacy for science teaching is a critical issue because of its effect on teaching quality and student learning in science. Harlen and Holroyd (1997) reported that in UK primary schools, teachers with low confidence tended to have a poor understanding of science concepts, and this severely limited the children's learning. Similarly, Appleton and Kindt (1999) reported that the poor quality of science teaching that occurred in many Australian primary schools was partly due to low levels of teacher confidence. Andersen, Dragsted, Evans, and Sørensen (2004) reported that the quality of science teaching in Danish elementary schools correlated with the teachers' self-efficacy scores. Petersen and Treagust (2014) noted that science was one of the least taught subjects in Australian primary schools and argued the importance of examining the self-efficacy beliefs of the teachers involved.

It should be noted that this pattern of low science teaching self-efficacy among primary teachers does not necessarily apply to secondary science teachers. Savran and Çakiroglu (2003) compared primary and secondary science preservice teachers, and found that the secondary group were more efficacious than their primary counterparts. Haigh and Anthony (2012) however, warned that secondary science teachers may feel more efficacious in some science topic areas compared to other science topic areas.

\subsection{Measurements of Specific Science Teaching Self-Efficacy Beliefs}

In many studies, science teaching self-efficacy has been measured as a general construct, and these studies have tended to use broadly focused instruments such as the Science Teaching Efficacy Belief Instrument (STEBI versions A and B) developed by Enochs and Riggs (1990). In recent years however, it has been recognized that teachers may hold different levels of efficacy about different aspects of science teaching. For example, studies have focused on efficacy for chemistry teaching (Uzuntiryaki, 2008), teaching science by inquiry (Seraphin, Philippoff, Parisky, Degnan, \& Warren, 2013), integrating Facebook into teaching (Blonder \& Rap, 2017), teaching socioscientific issues (Kilinç et al., 2014), and integrating ICT into science (Annetta, Frazier, Folta, Holmes, Lamb, \& Cheng, 2013).

However, there is an important omission from this research. At this time, there appears to have been no study that has investigated teacher efficacy beliefs about their ability to enhance students' long-term interest in science. 


\section{The Present Study}

Very little is known about preservice teachers' efficacy for enhancing students' long-term interest in science. Yet enhancing student interest in science is a significant issue internationally, and it has been identified as a syllabus aim at both primary and secondary level in Australia. Thus, it is today's preservice teachers who will be faced with the task of building an interest in science among their future students. Self-efficacy beliefs can provide a powerful predictor of teacher actions. Therefore, if preservice teachers confidently believe they can enhance student interest in science then they will be more likely to implement the actions that are necessary to make that happen. Consequently, the aim of this study was:

To identify preservice primary teachers' and preservice secondary science teachers' self-efficacy beliefs about their ability to enhance students' long-term interest in science.

\section{Methods}

This study involved a mixed methods design, as data were collected using survey and interview. This allowed validity and reliability to be established by triangulation as well as quantitative analysis.

\subsection{Participants}

The participants were 252 preservice teachers who attended a university in south-eastern Australia. A criterion for selection was that the participants should have completed, or at least be currently participating in, their science methods units. The reason for this was that the science methods studies would perhaps be where students might have learnt how to teach science in a way that would maximise student interest. Four groups of participants were involved, namely second year primary teaching undergraduates $(\mathrm{N}=118)$, third year primary teaching undergraduates $(\mathrm{N}=103)$, third year secondary science teaching undergraduates $(\mathrm{N}$ $=22$ ), and second year secondary science teaching masters students who had already completed a previous degree in another domain $(\mathrm{N}=9)$. The disparity in numbers between primary and secondary participants was to be expected because the university where the study was conducted prepares considerably more primary teachers than secondary science teachers.

All participants were volunteers. They were informed that participation or non-participation in this study would not be linked to their grades, and that their responses would be anonymous and confidential. The data collection was carried out by a person who was not otherwise involved with any of the courses.

\subsection{The Science Education Studies}

The preservice primary teaching program contained a science content unit which students normally completed in their first year, and a science methods unit of one semester which was normally undertaken in second year. Informal discussion with the instructors on these units revealed that they were aware that many preservice primary teachers do not have positive attitudes towards science. Consequently, they made it a priority to not only teach science and the methods for teaching science, but also to provide these preservice teachers with positive 
experiences that would hopefully help to build their interest and enthusiasm for the subject. As such, the instructors reported that they regularly included hands-on activities that were relevant to primary schools, and often included personal anecdotes, visual demonstrations, or interesting facts in order to build interest as well as knowledge.

In contrast, the science content studies in the preservice secondary teacher undergraduate program consisted of a standard major in science, and the masters students had already completed a major in science. These students were required to complete at least two science teaching methods units. According to the instructors, these units included extensive discussion about how to teach science and how to make science lessons interesting to adolescents, by using techniques such as relating it to real life, using student-centred teaching strategies such as inquiry, and by integrating ICT into lessons.

\subsection{Data Collection and Analysis: Survey}

The main purpose of the survey was to measure preservice teachers' self-efficacy for enhancing students' long-term interest in science. As there appeared to be no pre-existing survey of this type, it was necessary to develop one for this study. An initial list of 12 items was created. Each item was linked to a four point Likert scale (Strongly Agree, Agree, Disagree, Strongly Disagree). Some items were positively worded and others negatively worded, in order to minimize repetitive answering. To analyse this survey, the responses for each item were able to be coded using a scale of 1 (low self-efficacy) to 4 (high self-efficacy), and the negatively worded items were reverse coded.

This survey was administered to all four groups of preservice teachers (second year primary, third year primary, secondary undergraduates, and secondary masters). A total of 290 surveys were distributed during lectures and tutorials, and 252 completed surveys were received, indicating a response rate of $87 \%$. A Principal Components Factor Analysis was then conducted on the twelve items. Two main factors were extracted, accounting for $32.84 \%$ and $12.60 \%$ of the variance respectively. Only the first factor was retained. It contained nine items, all with loadings greater than 0.5 on the first factor. The nine items and their factor loadings are presented in Table 1.

Table 1. The self-efficacy to enhance students' long-term interest in science scale

\begin{tabular}{|lc|}
\hline Item & Factor Loading \\
\hline I do not have the strategies to enhance students' general liking for science. & 0.67 \\
I know how to increase students' long-term interest in science. & 0.65 \\
I have the skills to increase students' long-term interest in science. & 0.65 \\
I know how to motivate students' general interest in science. & 0.61 \\
If I had students who did not like science, I am sure I could get them to like science. & 0.54 \\
My university program has prepared me well to enthuse students about science. & 0.66 \\
I believe I can help students develop an enjoyment of science. & 0.55 \\
I am confident that my future students will learn to love science. & 0.67 \\
My university program has not prepared me with strategies to increase students' long- & \\
term interest in science. & 0.65 \\
\hline
\end{tabular}




\section{$\Lambda$ Macrothink}

Global Journal of Educational Studies

ISSN 2377-3936

2019, Vol. 5, No. 1

To examine the internal consistency of this nine-item scale, a reliability test was conducted. The Cronbach's Alpha reliability score for the scale was 0.82. Inspection of these items showed they all related to preservice teachers' self-efficacy that they could increase students' interest in science. As a result, the scale was labelled "Efficacy to Enhance Students' Long-term Interest in Science". Although participants had responded to all 12 items in the initial instrument, only their responses to these nine items were used for further analysis. Analysis of variance (ANOVA) and an independent samples t-test were used to compare the four groups of participants (second year primary, third year primary, undergraduate secondary, masters secondary) for efficacy to enhance student interest in science.

\subsection{Data Collection and Analysis: Interviews}

The main purpose of the interviews was to provide an additional source of data, for the purposes of triangulation. A guided interview approach was used, in which guide questions were followed by further probing and clarifying questions. The interview guide questions were developed from pilot interviews with two preservice teachers who were not included in the final study. The interview guide questions were,

1) Do you feel confident that you could increase your students' long-term interest in science when you become a teacher? Please explain.

2) On a scale of 1-10 with 10 being the highest how confident are you that you can increase your students' long-term interest in science when you become a teacher? Please explain.

Note that the term "confidence" was used in the interviews, because the pilot interviews had indicated that participants related more easily to it than to the term self-efficacy. Thirteen students were interviewed: eight preservice primary teachers and five preservice secondary science teachers. In the primary group, there were 6 females and 2 males. In the secondary group, there were two Masters students (a male and a female) and three undergraduates comprising two males and one female. Thus, the interviewees included a variety of participants who represented the main groups involved in the study, and both genders. As all of these participants volunteered to be interviewed, it raised the question of whether these were individuals who were naturally more positively efficacious. This did not appear to be the case however, because as will be shown in Table 2, most of the interviewees were in the moderate range for efficacy to enhance interest in science, with some more positive and others more negative.

Each interview lasted approximately 10 minutes and was recorded and transcribed verbatim. Standard qualitative techniques involving inductive thematic analysis (Braun \& Clarke, 2006) were used to analyse the transcripts. This involved the initial coding of the responses based on the literal wordings used by the students then combining of those into larger categories if they seemed to express the same idea.

\section{Results}

\subsection{Survey Results}

Possible scores on the "Efficacy to Enhance Students' Long-term Interest in Science" scale 


\section{Macrothink}

Global Journal of Educational Studies

ISSN 2377-3936

2019, Vol. 5, No. 1

ranged from 9 (i.e., $9 \times 1)$ to $36(9 \times 4)$ so the mid-point on the scale was 22.5 . The means for all four groups (second year primary, third year primary, secondary undergraduate, secondary masters) are presented in Figure 1, which shows that all were above the midpoint score of 22.5. This suggests that all groups had positive levels of self-efficacy for enhancing students' long-term interest in science.

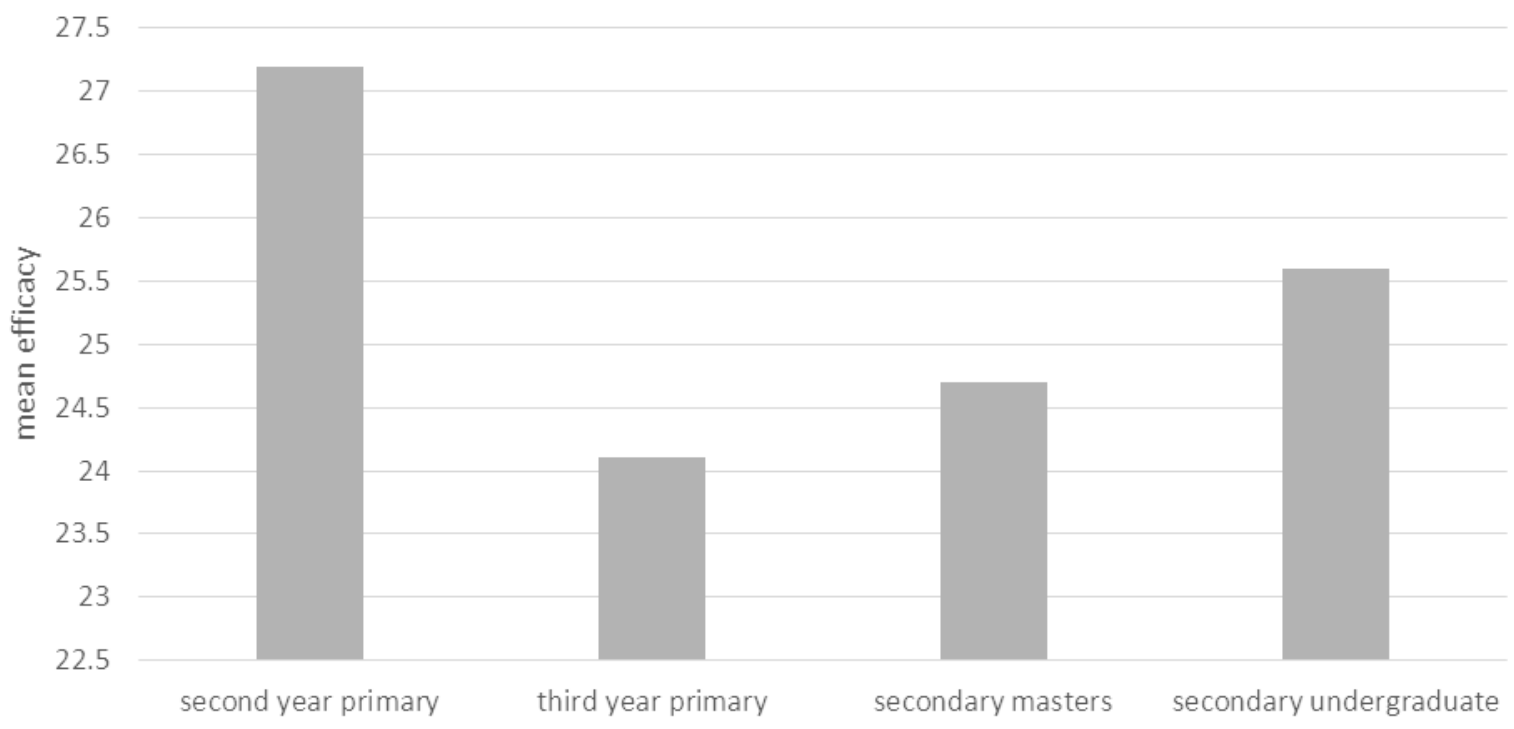

Figure 1. Mean self-efficacy scores for each group

A one-way ANOVA was conducted to compare differences in self-efficacy among the four groups. The ANOVA was significant: $F(3,252)=21.88, p=.000$. Post hoc tests (Fisher's Least Significant Difference test) revealed there was a significant difference between the second year primary group and each of the other groups, that is, the third year primary ( $p$ $=.000)$, the secondary Masters $(p=.013)$, and the secondary undergraduates $(p=.014)$. This suggested that the second year primary preservice teachers had greater self-efficacy than the other three groups. This result may be related to the timing and content of the science methods units, as explained in the Discussion.

In addition, an independent samples t-test was conducted to compare the combined primary against combined secondary participants. No significant difference was found, between the primary group $(M=25.7, S D=3.22)$ and the secondary group $(M=25.35 S D=2.61) ; t(252)$ $=.729, p=.242$. This suggested that there was not an overall difference between the efficacy of the primary participants and that of the secondary participants.

\subsection{Interview Results}

Among the primary interviewees, responses to the first interview question (Do you feel confident that you could increase your students' long-term interest in science when you become a teacher? Please explain.) revealed a range of confidence levels, from moderately 
negative, to neutral, and moderately positive. The primary interviewees explained that during the science methods units at university they had been taught how to arouse students' interest, and this had positively affected their confidence (e.g., "We have been taught various techniques on how to engage students in science using interesting information which would gain their interest" male third year primary). Positive practicum experiences had also positively influenced their confidence: "I think science is also pretty easy in the classroom. It's a fun subject, because the kids can work with hands-on and do practical stuff' (female third year primary). However, factors that negatively influenced their confidence were: first, their lack of experience as teachers (e.g., "because I am not a teacher yet. I'm still a preservice teacher" female third year primary); or second, because they didn't see themselves as science specialists (e.g., "My strengths are more the social sciences and humanities. I am not very maths and science. They are not my strength" female third year primary). The techniques they suggested could be used to build student interest in science included doing experiments (e.g., "If it's very much just textbook then no-one is going to be engaged. No-one is going to be interested. So if you've got experiments, having hands-on. That needs to be in every lesson" male third year primary), and by modelling an interest in science (e.g., "I would model it myself. Showing things I might find interesting. You can introduce a topic by telling the children some interesting facts, something they might think is interesting, amusing or funny, or connecting with our past stories, so what we might have encountered as an adult. So that's modelling our interest in science" female second year primary).

Among the secondary interviewees, several made a point of emphasising the importance of developing their future students' interest in science (e.g., "I guess it's the foundation for methodical thinking and scientific thinking ... If you continue it from primary school and then you further continue it into high school, it will set people up for scientific thinking for after school. So whether you go to university or if you do a trade" male undergraduate; and "We need people who are scientifically literate and who are comfortable with science. I also think it's important because perhaps for some types of students there might be a feeling that science is not for them" male undergraduate). The secondary interviewees confirmed that during their science methods units at university they had been taught techniques for arousing student interest (e.g., "We obviously talk about it in the science methods courses and other education courses. And we discussed it and some ways how to do it" female secondary undergraduate). These techniques included relating science to things they can do outside of school (e.g., "In the class you can do the practical side of things that they can do at home. So they can go home and show their brothers or sisters or parents and that way they can sort of have an interest in it outside of school. And I think once it's outside of school you've got a bit of a start on their long-term interest" male secondary undergraduate), doing science experiments (e.g., "I believe in science being hands-on, those [activities] that students will enjoy and learn by doing in the science classroom rather than just observing and being dictated to. Involving the students in actually doing the science in conducting experiments, making their own observations and making their own interpretations" male secondary undergraduate), and relating it to the real world (e.g., "If you can relate it back to the student's background, their cultural understanding, integrate it with other subjects that they have been learning, then they can see the real big picture and how the learning relates to the real world" female secondary masters). Most of the 
secondary interviewees expressed moderate confidence. Many of them pointed out that they were still preservice teachers rather than inservice teachers, so their lack of classroom experience affected their confidence (e.g., "I feel quietly confident because at the moment I have only spent four weeks in the classroom, so I don't want to make any claims that I can do one thing or another just yet" male secondary undergraduate; and "To be honest, I'd probably think it's too early to say so there's probably a bit of lack of confidence there. But I believe once I learn ... once I become a half decent teacher after a couple of years of teaching I'd be able to [enhance interest in science]" male secondary masters). Some of the secondary interviewees stated that other factors apart from the teacher would probably affect their success in enhancing interest in science (e.g., " $50 \%$ of the impact comes from the home life, and teachers have $30 \%$ impact, so we are the second biggest and can try our best but community can be a big factor" female secondary masters).

Responses to the second interview question (On a scale of 1-10 with 10 being the highest, how would you rate your level of confidence for increasing your students' long-term interest in science when you become a teacher?) are shown in Table 2. Nearly all the interviewees were in the positive range for confidence, although there was more variation among the primary group. Apart from this difference in the spread of responses, no major differences were apparent between primary and secondary interviewees.

Table 2. Interviewees' level of confidence to enhance students' long-term interest in science

\begin{tabular}{|ccc|}
\hline Confidence Level & Primary & Secondary \\
\hline 8-10 (high) & 3 & 0 \\
$5-7$ (moderate) & 4 & 5 \\
3-4 (low) & 1 & 0 \\
$1-2$ (very low) & 0 & 0 \\
\hline
\end{tabular}

\section{Discussion}

\subsection{Preservice Primary Teachers}

From the survey, it was found that both groups of preservice primary teachers (second years and third years) had a positive level of efficacy that they could increase students' long-term interest in science. The interviews also revealed a moderately positive level of confidence among this group. These two data sets therefore triangulated well, suggesting an acceptable level of validity for this finding. According to the survey results, the second year cohort had a higher level of efficacy than the third year cohort. This may have been because the second years were currently participating in their science methods unit, so their experience would have been more recent than that of the third years who had completed their science methods the preceding year.

Unfortunately, there have been no previous studies of preservice primary teachers' self-efficacy for enhancing student interest in science. However, other studies have reported a general pattern of low self-efficacy for teaching science amongst primary school teachers. 


\section{Mll Macrothink}

Global Journal of Educational Studies

ISSN 2377-3936

2019, Vol. 5, No. 1

The Australian Academy of Science (2012) indicated that "Many writers have argued that primary teachers' limited science background erodes their confidence to teach science" ( $\mathrm{p}$. 194). Similarly, Appleton (2003) reported that one of the major reasons why elementary teachers avoid teaching science was because of a lack of confidence to teach the subject.

On the other hand, it has been found that preservice primary teachers can develop moderate to high self-efficacy for science teaching, due to their experiences in well-constructed science methods units. For example, Bleicher (2007) reported that "preservice teachers were not only perceiving higher science teaching self-efficacy, but also felt that their teaching would make a difference to student achievement" (p. 854). Similarly, Watters and Ginns (2000) argued that science methods units can be effective in enhancing preservice primary teachers' confidence to teach science. The results of the present study are not directly comparable to these because the present study focused on efficacy to enhance interest in science, rather than general efficacy to teach science. However, the results have indicated a similar pattern of moderately positive efficacy among preservice primary teachers who have participated in science methods units.

\subsection{Preservice Secondary Science Teachers}

The survey revealed that preservice secondary science teachers had a moderately positive level of efficacy that they could enhance students' long-term interest in science. The interviews also revealed that the preservice secondary teachers were moderately confident that they could increase students' interest in science. These two data sources therefore triangulated well in providing validity to this finding.

Unfortunately, there have been no previous studies of preservice secondary science teachers' self-efficacy for enhancing students' level of interest in science. However, these individuals have chosen to be science specialists, and they usually have positive attitudes towards science and science teaching in general (Akbulut \& Karakuş, 2011; Ates \& Saylan, 2015). Although the present study is not directly comparable to these, the findings are generally similar in suggesting a moderately positive level of efficacy.

\subsection{Comparison of Primary and Secondary Groups}

The t-test analysis of the survey data revealed that there was no overall difference in self-efficacy between the preservice primary teachers and the preservice secondary science teachers. This finding is interesting because it might be expected that preservice secondary science teachers would have a higher efficacy for all aspects of teaching science, because they are science specialists. However, this was not the case. One possible explanation for this is as follows. Silvia (2001) warned that most people who have strong interests give little thought as to how their interests develop-they enjoy their interests but are disinclined to question from where they came. This might apply to the preservice secondary science teachers, because they would presumably have a well-established interest in science (Akbulut \& Karakuş, 2011; Ates \& Saylan, 2015). On the other hand, the preservice primary teachers may have had recent, personal experience of the development of their own interest due to participation in their science methods units, because these had been partly intended to 
enhance these students' interest in science. This would not necessarily be unusual, since Jarrett (1999) reported that preservice primary teachers could develop enhanced interest in science through participation in a well-designed science methods unit. In this way, the roughly equal levels of confidence between the primary and secondary groups may have been due on the one hand to recent personal experience in interest development, which may have led the preservice primary teachers to believe they could achieve the same result with their future students; whereas on the other hand, the preservice secondary teachers may not necessarily have had recent personal experience of interest enhancement, but nevertheless believed they could do it because of their their own well-established interest in the subject and the ideas gained from their methods studies.

\section{Conclusions, Limitations, and Implications}

The nine-item survey developed for this study was unique, since it was designed to measure preservice teacher self-efficacy for enhancing students' long-term interest in science. The factor analysis and Cronbach's alpha, combined with triangulation with the interview data, suggested that it had acceptable levels of validity and reliability for the participants in this study. Comparison between the preservice primary teachers and the preservice secondary science teachers suggested that overall, their levels of self-efficacy were comparable and were moderately positive in strength. This is a welcome finding because teacher self-efficacy is widely recognised as a relatively accurate predictor of teacher behaviour. This suggests that if these levels of self-efficacy are maintained, then once they become practicing teachers they will have the disposition to make vigorous efforts to enhance their students' interest in science. Thus, the study has provided evidence that the teacher education studies in science have well-prepared these future teachers to engage with the difficult task of addressing the declining interest in science that has been identified among our youth.

The following limitations should be considered when evaluating the findings. First, this study was carried out at an institution in which the preservice teachers were taught how to arouse student interest during science lessons, but at other institutions the science methods instructors might have different approaches. In this way, preservice teachers' self-efficacy for enhancing interest in science may be influenced to a greater or lesser extent depending on what has been taught to them. Second, this study only included preservice teachers, so it does not necessarily apply to in-service teachers, who may have had varying degrees of teaching experience in science.

The main implication for research is as follows. One aspect of the research on science teaching self-efficacy that has not yet been addressed is the extent to which one's general science teaching self-efficacy is correlated (or not) with one's self-efficacy for more specific aspects of science teaching, such as efficacy for enhancing students' long-term interest in science. Previous studies (and also this one) have assumed that specific aspects of self-efficacy need to be measured separately, and while this may be correct, the extent of difference has not yet been evidenced in the research. In fact, the strong parallels identified in the Discussion section of this paper suggest it would be surprising if one's self-efficacy for science teaching in general was widely different to one's self-efficacy for enhancing student 
interest in science, at least among the participants in the present study.

Finally, there is an important implication for teaching. According to the interview transcripts, participants in the present study appeared to have gained their self-efficacy mainly from their science methods studies. In these units, techniques for arousing student interest were either discussed (as in the secondary) and/or personally experienced (as in the primary). This suggests that instructors at all institutions should ensure that such techniques are included in science methods units. In this way, our future teachers can begin to build the capacity to address the problem of declining student interest in science.

\section{References}

Ainley, M., Hidi, S., \& Berndorff, D. (2002). Interest, learning, and the psychological processes that mediate their relationship. Journal of Educational Psychology, 94, 545-561. https://doi.org/10.1037/0022-0663.94.3.545

Akbulut, Ö. E., \& Karakus, F. (2011). The investigation of secondary school science and mathematics pre-service teachers' attitudes towards teaching profession. Educational Research and Reviews, 6, 489-496.

Andersen, A. M., Dragsted, S., Evans, R. H., \& Sørensen, H. (2004). The relationship between changes in teachers' self-efficacy beliefs and the science teaching environment of Danish first-year elementary teachers. Journal of Science Teacher Education, 15, 25-38. https://doi.org/10.1023/B:JSTE.0000031461.68912.3d

Anderson, D., Bartholomew, R., \& Moeed, A. (2009, September). Confidence, Knowledge and Teaching Strategies: A Study of Pre-Service Science Teachers in a New Zealand University. Paper presented at the Annual Meeting of the British Educational Research Association, Manchester, UK.

Annetta, L. A., Frazier, W. M., Folta, E., Holmes, S., Lamb, R., \& Cheng, M. T. (2013). Science teacher efficacy and extrinsic factors toward professional development using video games in a design-based research model: The next generation of STEM learning. Journal of Science Education and Technology, 22, 47-61. https://doi.org/10.1007/s10956-012-9375-y

Appleton, K. (2003). How do beginning primary school teachers cope with science? Toward an understanding of science teaching practice. Research in Science Education, 33, 1-25. https://doi.org/10.1023/A:1023666618800

Appleton, K., \& Kindt, I. (1999). Why teach primary science? Influences on beginning teachers' practices. International Journal of Science Education, 21, 155-168. https://doi.org/10.1080/095006999290769

Ates, H., \& Saylan, A. (2015). Investigation of pre-service science teachers' academic self-efficacy and academic motivation toward biology. International Journal of Higher Education, 4, 90-103. https://doi.org/10.5430/ijhe.v4n3p90

Australian Academy of Science. (2013). Australian Academy of Science Annual Report 2012-13. 
https://www.science.org.au/files/userfiles/about/documents/2012-2013-annual-report.pdf

Australian Curriculum Assessment and Reporting Authority. (2015). The Australian Curriculum Science. Canberra, Australia: Australian Curriculum, Assessment and Reporting Authority.

Bandura, A. (1981). Self-referent thought: A developmental analysis of self-efficacy. In J. H. Flavell \& L. Ross (Eds.), Social Cognitive Development: Frontiers and Possible Futures. Cambridge, UK: Cambridge University Press.

Bandura, A. (1997). Self-Efficacy: The Exercise of Control. New York: Freeman.

Bleicher, R. E. (2007). Nurturing confidence in preservice elementary science teachers. Journal of Science Teacher Education, 18, 841-860. https://doi.org/10.1007/s10972-007-9067-2

Blonder, R., \& Rap, S. (2017). I like Facebook: Exploring Israeli high school chemistry teachers' TPACK and self-efficacy beliefs. Education and Information Technologies, 22, 697-724. https://doi.org/10.1007/s10639-015-9384-6

Board of Studies. (2013). NSW Syllabus for the Australian Curriculum: Science K-10 (Incorporating Science and Technology K-6) Syllabus. NSW, Australia: NSW Education Standards Authority.

Braun, V., \& Clarke, V. (2006). Using thematic analysis in psychology. Qualitative Research in Psychology, 3, 77-101. https://doi.org/10.1191/1478088706qp063oa

Danaia, L., Fitzgerald, M., \& McKinnon, D. (2013). Students' perceptions of high school science: What has changed over the last decade? Research in Science Education, 43, 1501-1515. https://doi.org/10.1007/s11165-012-9318-X

Enochs, L., \& Riggs, I. (1990). Further development of an elementary science teaching efficacy belief instrument: A pre-service elementary scale. School Science and Mathematics, 90, 695-706. https://doi.org/10.1111/j.1949-8594.1990.tb12048.x

Haigh, M. A., \& Anthony, G. J. (2012). Induction and efficacy: A case study of New Zealand newly qualified secondary science teachers. Journal of Science Teacher Education, 23, 651-671. https://doi.org/10.1007/s10972-012-9285-0

Harlen, W., \& Holroyd, C. (1997). Primary teachers' understanding of concepts of science: Impact on confidence and teaching. International Journal of Science Education, 19, 93-105. https://doi.org/10.1080/0950069970190107

Jack, B. M., Lin, H.-S., \& Yore, L. D. (2014). The synergistic effect of affective factors on student learning outcomes. Journal of Research in Science Teaching, 51, 1084-1101. https://doi.org/10.1002/tea.21153

Jarrett, O. S. (1999). Science interest and confidence among preservice elementary teachers. Journal of Elementary Science Education, 11, 49-59. https://doi.org/10.1007/BF03173790 
Kennedy, J., Lyons, T., \& Quinn, F. (2014). The continuing decline of science and mathematics enrolments in Australian high schools. Teaching Science, 60(2), 34-46.

Kilinç, A., Afacan, O., Polat, D., Demirci Güler, P., Yilditim, K., Demiral, Ü., Eroglu, B., Kartal, T., Sonmez, A., Iseri, B., \& Gorgulu, O. (2014). Preservice science teachers' belief systems about teaching a socioscientific issue. Journal of Turkish Science Education, 11, 79-102.

Linnenbrink-Garcia, L., Pugh, K. J., Koskey, K. L. \& Stewart, V. C. (2012). Developing conceptual understanding of natural selection: The role of interest, efficacy, and basic prior knowledge. Journal of Experimental Education, 80, 45-68. https://doi.org/10.1080/00220973.2011.559491

Mansfield, C. F., \& Woods-McConney, A. (2012). I didn't always perceive myself as a science person": Examining efficacy for primary science teaching. Australian Journal of Teacher Education, 37(10). https://doi.org/10.14221/ajte.2012v37n10.5

Oon, P. T., \& Subramaniam, R. (2011). On the declining interest in physics among students From the perspective of teachers. International Journal of Science Education, 33, 727-746. https://doi.org/10.1080/09500693.2010.500338

Palmer, D. H., Dixon, J., \& Archer, J. (2015). Changes in science teaching self-efficacy among primary teacher education students. Australian Journal of Teacher Education, 40(12). https://doi.org/10.14221/ajte.2015v40n12.3

Petersen, J. E., \& Treagust, D. F. (2014). School and university partnerships: The role of teacher education institutions and primary schools in the development of preservice teachers' science teaching efficacy. Australian Journal of Teacher Education, 39(9). https://doi.org/10.14221/ajte.2014v39n9.2

Potvin, P., \& Hasni, A. (2014). Analysis of the decline in interest towards school science and technology from grades 5 through 11. Journal of Science Education and Technology, 23, 784-802. https://doi.org/10.1007/s10956-014-9512-x

Randler, C., \& Bogner, F. X. (2007). Pupils' interest before, during, and after a curriculum dealing with ecological topics and its relationship to achievement. Educational Research and Evaluation, 13, 463-478. https://doi.org/10.1080/13803610701728295

Rennie, L. J., Goodrum, D., \& Hackling, H. (2001). Science teaching and learning in Australian Schools: Results of a national study. Research in Science Education, 31, 455-498. https://doi.org/10.1023/A:1013171905815

Renninger, K. A., Ewen, L., \& Lasher, A. K. (2002). Individual interest as context in expository text and mathematical word problems. Learning and Instruction, 12, 467-491. https://doi.org/10.1016/S0959-4752(01)00012-3

Sandholtz, J. H., \& Ringstaff, C. (2011). Reversing the downward spiral of science instruction in K-2 classrooms. Journal of Science Teacher Education, 22, 513-533. https://doi.org/10.1007/s10972-011-9246-z 
Savran, A., \& Cakiroglu, J. (2003). Difference between elementary and secondary pre-service science teachers' perceived efficacy beliefs and their classroom management beliefs. The Turkish Online Journal of Educational Technology, 2, 15-20.

Seraphin, K. D., Philippoff, J., Parisky, A., Degnan, K., \& Warren, D. P. (2013). Teaching energy science as inquiry: Reflections on professional development as a tool to build inquiry teaching skills for middle and high school teachers. Journal of Science Education and Technology, 22, 235-251. https://doi.org/10.1007/s10956-012-9389-5

Silvia, P. J. (2001). Interest and interests: The psychology of constructive capriciousness. Review of General Psychology, 5, 270-290. https://doi.org/10.1037/1089-2680.5.3.270

Skamp, K. (1991). Primary science and technology: How confident are teachers? Research in Science Education, 21, 290-299. https://doi.org/10.1007/BF02360483

Tröbst, S., Kleickmann, T., Lang-Schubert, K., Rothkopf. A., \& Möller, K. (2016). Instruction and students' declining interest in science; An analysis of German fourth- and sixth-grade classrooms. American Educational Research Journal, 53, 162-193. https://doi.org/10.3102/0002831215618662

Tschannen-Moran, M., \& Woolfolk Hoy, A. W. (2007). The differential antecedents of self-efficacy beliefs of novice and experienced teachers. Teaching and Teacher Education, 23, 944-956. https://doi.org/10.1016/j.tate.2006.05.003

Tschannen-Moran, M., Woolfolk Hoy, A. W., \& Hoy, W. K. (1998). Teacher efficacy: Its meaning and measure. Review of Educational Research, 68, 202-248. https://doi.org/10.3102/00346543068002202

Tytler, R. (2007). Re-imagining science education: Engaging students in science for Australia's future. Teaching Science, 53, 14-17.

Uzuntiryaki, E. (2008). Exploring the sources of Turkish pre-service chemistry teachers' chemistry self-efficacy beliefs. Australian Journal of Teacher Education, 33(6). https://doi.org/10.14221/ajte.2008v33n6.2

Watters, J., \& Ginns, I. (2000). Developing motivation to teach elementary science: Effect of collaboration and authentic learning practices in preservice education. Journal of Science Teacher Education, 11, 301-321. https://doi.org/10.1023/A:1009429131064

White, E. L., \& Harrison, T. G. (2012). UK school students' attitudes towards science and potential science-based careers. Acta Didactica Napocensia, 5(4), 1-10.

\section{Copyright Disclaimer}

Copyright for this article is retained by the author(s), with first publication rights granted to the journal.

This is an open-access article distributed under the terms and conditions of the Creative Commons Attribution license (http://creativecommons.org/licenses/by/3.0/). 